\title{
Brúða Mameligu
}

18 g var bara stelpa og pegar kris, rétturinn, kom saman mátti ég ekki segja orð nema ég væri spurð og ef ég var vitni, sakborningur eða polandi í málinu. Ef ég vildi taka til máls, varo ég fyrst að ávarpa einn af körlunum í mínum ættflokki, pabba minn, bróður eða eiginmann. Annars hefði verið litið á mig sem illa uppalinn kvenmann og enginn hefði hlustað á mig.

Á líkvökunum réðuð pið karlmennirnir líka öllu. Við konurnar höfðum ekkert að segja og purftum að láta okkur nægja að hlusta á ykkur, færa ykkur te eða áfengi, nú eða halda á ykkur hita. Ætli við höfum bara ekki verið aldar upp á pennan hátt og okkur datt ekki einu sinni í hug að kvarta. Við höfðum sætt okkur við hlutskipti okkar sem konur, pað er að segja sem dóttir, systir, eiginkona eða móðir.

Pað sem pið karlarnir vitið ekki er að við konurnar töluðum saman um okkar mál. Og stundum, ef ekki varð hjá pví komist, sögðum við vinum okkar frá pví sem máli skipti.

Nú er allt breytt. Vissulega erum við enn undir ykkur karlana settar en við megum tala hátt og snjallt án pess að pið getið paggað niður í okkur. pið getið hlustað á okkur ef pið viljið eða látið pað ógert!

En í kvöld ætla ég, sem er orðin amma, nei, hvað er ég að rugla, langamma, að segja ykkur sögu sem flestar Rómakonur á mínum aldri kunna. Pið karlarnir segið hana stundum líka pegar ég er ekki hér en pið segið hana ekki eins og á að gera. Pess vegna ætla ég að grípa petta tækifæri nú á kvöldvökunni og segja ykkur söguna í síđasta sinn. Pannig mun hún festast í minni ykkar svo pið getið sagt afkomendum ykkar hana. 
Раð eru ekki margir ykkar sem kunnið að lesa og skrifa og engin okkar kvennanna hefur lært pað. Ef ég hefði kunnað að skrifa hefði ég sett pessa sögu á blað en ég get pað ekki. Рað er nú leitt!

Semsagt, ég hlýt að hafa verið um pað bil fimmtán ára gömul. Ég var enn bara stelpukrakki en samt var pabbi minn farinn að leggja á ráðin um að gifta mig. Af pví að við vorum svo fátæk og nokkrir gullpeningar hefðu dugað til að bæta hag fjölskyldunnar. Ég átti tvo eldri bræður og ég veit ekki hversu mörg yngri systkini og við krakkarnir purftum hlý föt. Ég átti bara einn kjól og fram að pessu hafði ég alltaf gengið berfætt. Við bjuggum í Asíuhluta Rússlands og par voru margir jafn fátækir og við.

Við vorum stödd í stórum bæ. Рað var markaðsdagur. Við höfðum slegið upp búðum fyrir utan bæinn og aldrei pessu vant hafði faðir minn beðið mömmu að taka mig með á markaðinn. Hann vildi að ég hjálpaði henni við innkaupin. Og svo má heldur ekki gleyma að ég var komin á giftingaraldur! Pannig að kannski myndi eitthvað gerast á markaðnum ...?

Dagurinn var langur, en af og til fékk ég að leika lausum hala. Pegar Mamo purfti ekki á hjálp minni að halda skrapp ég frá í nokkrar mínútur, samt ekki of langt, til pess að horfa á alla pessa fallegu hluti sem ég hafði engin efni á að kaupa. Foreldrar mínir höfðu sagt mér að stela engu. Pess vegna gerði ég pað ekki pví ég var hræddari við pabba en við lögregluna.

Fólkið á markaðnum skiptist í tvo hópa; ég áttaði mig á pví síðar. Annars vegar voru pað Evrópubúar, hins vegar Asíubúar. Ég hafði bara áhuga á peim sîðarnefndu. En hvað stelpurnar á mínum aldri voru fallegar! Í pessum fagurlituðu klæðum, með hlýja klúta á höfðinu og í glæsilegum ilskóm. Og fullt af gulli um hálsinn, handleggi og ökkla og einstaklega fallega eyrnalokka. Ef einhver pessara stelpna lét svo lítið að horfa til mín pá skein fyrirlitning úr augum hennar. Ég sagði við sjálfa mig að svona ríkt fólk gæti ekki verið til. Og pegar pær sáu mig hugsuðu pær að svona fátækt fólk gæti ekki verið til. Рað var greinilegt að við vissum lítið hver um aðra.

Pegar ég var búin að svala forvitni minni um pessar konur langaði mig að sjá karla sem ég hafði ekki hitt áður. Deir voru ekki margir. Konurnar og stelpurnar töluðu við mig. Pær spurðu hvernig fjölskylda mín hefði pað. Ein peirra spurði meira að segja: 
-En hvernig stendur á pví að pú ert enn ógift? Mín terka [stúlka] sem er jafngömul pér, er gift.

Раð eina sem ég gerði var að yppa öxlum. Рað væri nær að spyrja pabba minn en mig.

Giftast? Hvaða unga stúlka hugsar ekki um að giftast? Pað gat verið lausn við mínum vandamálum, leið til að geta klæðst eins og aðrar stúlkur og eiga kannski nokkra skartgripi? Af hverju ekki? Hver okkar hefur ekki látið sig dreyma um pann sem Gayziés [hinir] kalla „draumaprinsinn“?

Af og til, eftir að hafa gengið um dálitla stund á markaðinum, fór ég aftur pangað sem pabbi var með vörurnar sínar. Hann var með til sýnis koparáhöld sem hann hafði sjálfur búið til. Hann leit út fyrir að vera ánægður. Eflaust hafði salan gengið vel. Við borðuðum saman í hádeginu. Foreldrar mínir hlógu eins og pau væru nýgift. Líklega var petta sjálf ástin.

Ég hafði oft gengið fram hjá búð par sem hægt var að kaupa alls konar leikföng. Ég porði ekki einu sinni að stoppa til að horfa af pví að ég vissi að ekkert af pessu var fyrir mig. Ég hafði aldrei átt leikföng. Bræður mínir og systur ekki heldur. Við vorum svo fátæk að faðir minn gat ekki leyft sér að eyða einu kópeki í slíkan óparfa. En mikið langaði mig að eignast fallega brúðu! Pó ekki væri nema einu sinni! Auðvitað kom pað fyrir að við systurnar bjuggum til dúkkur úr gömlum tuskum.

-Hvaða brúða finnst pér fallegust?

раð stóð einhver fyrir aftan mig og ávarpaði meðan ég horfði á leikföngin. Og á rómísku. Ég sneri mér við og sá pá ungan mann sem brosti til mín. Hann var svo myndarlegur! Mér varð strax ljóst að hann var „draumaprinsinn minn“. Hann var á bilinu átján til tuttugu ára, var í fallegum fötum, með hatt á höfðinu og klút um hálsinn sem haldið var saman með gullnælu. Hann var með marga hringi á fingrunum, og peir voru allir úr gulli. Hann var höfðinu hærri en ég.

Hann virtist bíða eftir pví að ég svaraði honum en ég var svo undrandi að ég kom ekki upp einu orði. Hann sagði aftur:

-Ég spurði pig hvaða brúða pér pætti fallegust?

Ég beitti mig hörðu og svaraði:

-Pær eru allar fallegar.

-Eflaust, en ekki eins fallegar og pú. 
Ég leit undan, í uppnámi, pví enginn hafði slegið mér slíka gullhamra fyrr. Svo virti ég betur fyrir mér pennan mann sem hafði ávarpað mig. Hann var mjög myndarlegur, með mjótt yfirvaraskegg. Hann var dálítið fölur í framan, líklega vegna kuldans.

Án pess að biðja mig um leyfi og án pess að prútta, keypti hann fallega brúðu og rétti mér hana:

-Detta er gjöf frá mér!

-Af hverju? spurði ég.

-Til pess að pakka pér fyrir að vera svona falleg. Hvað heitirðu?

-Mameliga!

Petta var bara gælunafn en ég er enn kölluð Mameliga.

-Og hvað heitir pú? spurði ég svo.

-Igruska!

Seinna komst ég að pví að pað var líka gælunafn.

-Igruska, ég get ekki tekið við gjöfinni frá pér pví að foreldrar mínir - og pá sérstaklega faðir minn - munu spyrja mig hver hafi gefið mér brúðuna! Og hvers vegna.

-Diggðu hana samt. Við sjáum hvað setur. Hvar eru vagnarnir ykkar og tjöldin?

-Darna, svaraði ég og benti í áttina að tjaldbúðunum.

-Ég ætla að biðja föður minn að slá upp tjöldum nálægt ykkur í kvöld.

Hann rétti mér brúđuna og flýtti sér burt.

Ég vissi ekki hvað var til ráða. Ekki gat ég farið aftur með brúðuna til sölukonunnar. Ég gat heldur ekki falið hana. Pví hljóp ég til mömmu og sagði henni allt af létta. Pegar pabbi sá að við vorum að tala saman, kom hann og vildi vita meira. Hann hlustaði á mig og spurði svo.

-Pessi brúða hefur kostað að minnsta kosti tíu rúblur; maðurinn er pví annaðhvort vel efnaður eða brjálaður. Dú segir að hann heitir Igruska. En sagði hann pér hvað faðir hans hét, eða ættflokkurinn?

- Nei, hvorugt.

-Kona góð, sagði faðir minn við móður mína, geymdu brúðuna og láttu engan sjá hana. Við sjáum hvað gerist í kvöld.

Frá pví andartaki vakti ég yfir dýrmætu brúðunni minni og beið pess í ofvæni að fjölskylda Igruska léti sjá sig. Foreldrar mínir hljóta að hafa velt pví fyrir sér hvort ég væri enn lítil stelpa sem lætur 
heillast af gjöf, eða ung kona sem práir barn. Hvað systrum mínum viðkom pá dauðöfunduðu pær mig allar. Í peirra augum var pessi brúða líka pað fallegasta sem hægt var að hugsa sér.

Ég kunni hvorki að lesa né skrifa, enn sîður að telja. Ég kann pað reyndar ekki enn. En mér fannst tíminn líða hægt. Af og til leit ég út fyrir tjaldið eða sendi eina af systrum mínum til að gá hvort nýtt fólk væri á ferðinni.

Loksins sá ég prjá vagna sem nálguðust, hver á eftir öðrum. „Parna koma pau!“ hrópaði ég upp yfir mig. Ég var alveg viss. En ég porði ekki að stinga nefinu út af ótta við að einhver sæi mig. Hjartað barðist um í brjósti mér. Ég prýsti brúđunni að mér eins fast og ég gat pví ég var dauðhrædd um að hún yrði tekin af mér.

Ég lagði við hlustir til að vita hvað fór fram fyrir utan tjaldið en systur mínar höfðu svo hátt að ég heyrði ekki neitt. Pessar mínútur voru óendanlega langar! Síðan heyrði ég rödd móður minnar:

-Mameliga, komdu og hjálpaðu mér!

En hvernig gat ég farið án brúðunnar? Hver átti að gæta hennar á meðan ég væri í burtu? Á endanum neyddist ég til skilja hana eftir á rúminu og ég hótaði systrum mínum:

-Ég banna ykkur að snerta hana, annars sting ég úr ykkur augun!

Ég gat ekki óhlýðnast mömmu, pá hefði pabbi komið að sækja mig eða einn bræðra minna og peir hefðu dregið mig út. Pess vegna hljóp ég til mömmu og spurði:

- Hvað, Mamo?

-Hitaðu te handa föður pínum og gestunum.

Ég horfði í flýti á viðstadda. Ég sá marga karla sem voru ógnvekjandi. Peir voru glæsilegir til fara: fötin peirra voru dýr og vönduð og hnapparnir úr silfri. En peir vöktu með mér ótta.

Ég fékk á tilfinninguna að peir vissu hver ég væri vegna pess að peir mældu mig út og pað gerði mig hrædda. Svona leið mér að minnsta kosti.

Í samanburði við mömmu mína voru konurnar peirra eins og prinsessur. $\mathrm{Pað} \mathrm{var} \mathrm{bara} \mathrm{hægt} \mathrm{að} \mathrm{sjá} \mathrm{svona} \mathrm{konur} \mathrm{í} \mathrm{draumi.} \mathrm{Pær}$ horfðu líka á mig, en pær brostu. Ein peirra var ung stúlka eins og ég og var pví ekki með klút á höfðinu; hún kom til mín og sagði:

-Á ég að hjálpa pér? 
Ég horfði á hana í smástund. Hún stóð parna og brosti út að eyrum, með hendur fyrir aftan bak. Svo bætti hún við:

-Ég er systir Igruska.

Hún vissi semsagt allt.

-Dú gætir lagt á borðið. Mamo lætur pig fá servéttur.

Hún hófst handa. Hún var semsagt systir Igruska, en hann sá ég hvergi. Parna voru samt allmargir ungir ógiftir menn. Petta var bara forleikurinn. Ég pjónaði til borðs með mömmu og systur Igruska, eins og ég gerði reyndar alltaf pegar faðir minn fékk gesti. Um kvöldið var brugðið út af venjunni: Gestirnir, eða öllu heldur konur peirra, settu lág borð og gullfallegar mottur fyrir framan tjaldið og báru fram alls konar mat; pað var nægt fuglakjöt handa öllum og alls kyns drykkir.

Aldrei pessu vant bað mamma mig ekki um að hjálpa til. Рað kom mér á óvart en ég porði ekki að spyrja hvers vegna. Ein af systrum mínum, sem var ári yngri en ég, var á pönum fram og til baka og hún sagði mér frá öllu sem gerðist. Mér var auðvitað alveg ljóst að tilefnið væri mikilvægt pví að petta var ekki í fyrsta sinn sem slíkt gerðist. Skyndilega kom systir mín og sagði við mig:

-Veistu hvað, раð var verið að biðja um hönd pína!

Ég leit niður og táraðist en ég vissi ekki hvort pað var af gleði eða skömm.

-Hefurðu séð mannsefnið pitt? spurði systir mín.

Mannsefni? Mér fannst hún fara aðeins of geyst. Pað var bara búið að biðja um hönd mína og pað var ómögulegt að vita hvort faðir minn yrði pví sampykkur.

-Hann er svo myndarlegur!

Systir mín var enn meiri krakki en ég.

-Dú segir ekki neitt! Viltu samt ekki giftast?

-Ég geri pað sem pabbi ákveður!

Ég hafði heyrt pessa setningu í hvert sinn sem ein af vinkonum mínum hafði fallist á að ganga í hjónaband. Ég gat ekki getið mér til um ásetning foreldra minna paðan sem ég horfði á pau. Bræður mínir hlutu að vera kátir vegna pess að peir gætu nú sjálfir kvænst fyrir peningana sem pabbi bæði föður Igruska um. Litlu systur mínar voru ennpá of ungar til að skilja hvernig mér leið. Dúkkan 
mín var pað eina sem ég gat huggað mig við og ég prýsti henni að mér.

Pegar mamma kom inn í tjaldið voru konur úr fjölskyldu Igruska með henni. Pær héldu á klæðnaði. Pær brostu og nokkrar peirra sungu.

-Mameliga, faðir pinn féllst á að gifta pig.

-Mamo!

Ég hrópaði upp yfir mig og kastaði mér í fangið á mömmu, eins og smástelpa, og svo fór ég að hágráta.

-Vertu róleg, vinan, pú ferð nú ekki strax. Í kvöld höldum við upp á trúlofunina en brúðkaupið verður ekki fyrr en eftir ár. Leyfðu móður Igruska og systrum að klæða pig!

Konurnar umkringdu mig; pær tóku mig úr lörfunum og klæddu mig í ný föt. Ég stóð hreyfingarlaus og var ekki með sjálfri mér. Ég skildi ekki neitt í neinu. Hvað var eiginlega að gerast? Um morguninn hafði ég bara verið áhyggjulaus stelpa en nú var ég orðin kona, eða næstum pví.

Pessar konur kunnu vel til verka. Pegar pær höfðu klætt mig, náđu pær í trébala og sungu á meðan pær pvoðu mér og greiddu. Að lokum létu pær á mig eyrnalokka og settu á mig hringa. Ég var orðin ein af peim. Nú var pað ég sem var brúða.

Móðir Igruska krækti perlufesti um hálsinn á mér, auðvitað ekki úr alvöru perlum. Ég horfði ósjálfrátt á dúkkuna mína sem lá á rúminu og öllum til furðu tók ég hana og vafði perlufestinni sem var nýbúið að setja á mig marga hringi í kringum hálsinn á henni. Allar konurnar skellihlógu, líka Mamo. Í peirra augum var ég enn barn, en mér fannst ég vera fullorðin. Á pennan hátt vildi ég heiðra brúðuna mína, brúðuna sem hafði gert mér kleift að hitta „draumaprinsinn“.

Раð var komið með spegil svo að ég gæti séð sjálfa mig og í skímunni af lampa sá ég konu sem var ekki lengur ég, petta var önnur Mameliga.

Nú sungu konurnar fullum rómi. Pær leiddu mig út úr tjaldinu til að sýna körlunum mig. Ég fór hjá mér og porði ekki að horfa á pá. -Líttu upp! skipaði Mamo mér.

Ég varð að hlýða, horfði bara á pabba og sá að hann var líka með tárin í augunum. 
-Taté! sagði ég bara.

Hann svaraði mér ekki en sagði við hina, skjálfandi röddu:

-Ef ég hefði vitað að Mameliga væri svona falleg hefði ég beðið um helmingi fleiri gullpeninga.

Allir voru glaðir. Faðir Igruska stóð upp og kom og kyssti mig á ennið. Á borðinu stóð plotchka (trúlofunarflaska skreytt festi með gullpeningum); hann tók festina og peningana sem héngu á henni og setti um hálsinn á mér.

-Detta er mín bori (tengdadóttir)! Ég vil að allir viti pað!

Annar karlmaður spurði mig hvort ég kynni að dansa.

-Hún hefur ekki gert neitt annað sîđan hún fæddist! svaraði mamma.

Nokkrir ungir menn náđu í hljóðfærin sín og fóru að spila lag sem allir pekktu. Ég vaggaði höfðinu. Konurnar klöppuðu saman höndunum og hvöttu mig áfram. Tónlistin hreif mig, ég dansaði hraðar og hraðar og stóð á sama um hvað aðrir myndu segja. Рað eina sem komst að í huga mér var að ég hafði fundið draumaprinsinn minn, en hvar var hann?

Næsta morgun tók mamma fallegu fötin og skartgripina sem mér höfðu verið gefnir við trúlofunina. Hún klæddi mig í önnur föt, sem er vissulega rétt að hentuðu betur, og ilskó. Mér var leyft að hafa um hálsinn festina með gullpeningunum sem var til merkis um að ég væri unnusta Igruska og að aðrir karlar mættu ekki biðja um hönd mína.

Ég reyndi að láta lífið ganga sinn vanagang en pað var ekki auðvelt. Aðrar stúlkur á giftingaraldri voru stöðugt í kringum mig, bæði úr mínum ættflokki og öðrum. Systur Igruska og frænkur slógu mér gullhamra án afláts. Pær vissu ekki hvernig pær gátu hjálpað mér. Ég var í skýjunum.

Okkar siðir leyfa ekki ungum ógiftum mönnum og stúlkum að tala saman nema pau séu heitbundin en pó ekki hvenær sem er.

Ég hélt áfram að hjálpa pabba á markaðnum. Ég hélt líka áfram að ráfa um, en nú fékk ég aldrei að vera ein. Ein af systrum Igruska fylgdi mér hvert sem ég fór. Ég held að hún hafi verið að gæta mín. Ég gekk oft fram hjá leikfangabúðinni par sem örlög mín höfðu ráđist. 
Um kvöldið, eins og öll kvöld, hittumst við unga fólkið og sungum og dönsuðum í einu tjaldanna. Рað voru margir í kringum mig og alltaf verið að óska mér til hamingju. Igruska var parna líka. Ég reyndi að forðast að horfa í augun á honum en gat pað ekki. Parna var lífsförunautur minn, sá sem ég myndi eyða ævinni með, og ég blygðaðist mín svo mikið að ég gat ekki talað við hann, sérstaklega pegar bræður mínir tveir voru viðstaddir. Sá eldri peirra kom til mín og sagði:

-Litla systir, við ætlum að leyfa ykkur að vera ein saman í smástund. Við segjum foreldrunum ekki frá pví, en vertu prúð!

Ég gat ekki trúað pví að bróðir minn, sem hafði alltaf verið strangur við mig, gæti verið svona góður. Hann lét sig hverfa, með öllum hinum, og fór í annað tjald. Loksins vorum við ein!

Igruska gekk til mín. Ég titraði og skalf. Hann tók um hendurnar á mér og hélt peim í sundur til að geta virt mig betur fyrir sér:

-Dú ert enn fallegri en pegar ég sá pig fyrst!

Ég porði ekki að opna munninn. Hann bætti pví við:

-Segðu mér hvað pig vantar. Ég bið mömmu um að láta pig fá раð.

-Mig vantar ekki neitt; ég hef aldrei átt svona mikið.

-Pig mun ekki skorta neitt. Ég mun vaka yfir pér, jafnvel úr fjarska. En pað er eitt sem ég vil að pú segir mér: Ertu alveg sátt við að verða konan mín?

-Pú veist pað, svaraði ég.

-Já, en mig langar að heyra pig segja pað.

Við hlustuðum á sönginn og köllin í peim sem höfðu fært sig yfir í annað tjald til að trufla ekki okkar fyrsta fund.

-Ég virði föður pinn og honum finnst pú vera of ung til að giftast. Hann bað um eins árs frest. En eitt ár er langur tími. Hvað finnst pér?

-Ég mun alltaf hlýða föður mínum. Ekki búast við pví að ég brjóti gegn vilja hans.

-Faðir minn borgaði með gullpeningum upphæðina sem faðir pinn setti upp. Pú tilheyrir mér núna. En ég vil síst af öllu valda pér sársauka. Ég veit ekki hvenær, en áður en eitt ár er liðið kem ég að ná í pig. Vertu tilbúin. Ég verð sektaður af kris en ég mun borga. Ekki gleyma bessu, ég kem! 
Og áđur en ég gat svarað flýtti hann sér út úr tjaldinu. Ég vissi ekki hvort hinir hefðu heyrt samtal okkar. Igruska hafði ekki beðið eftir að ég svaraði. Ég var svo ung, pað er rétt, en ég vildi alls ekki sverta nafn föður míns með pví að hlaupast á brott. Hvað átti ég að gera? Ég held að ef Igruska hefði beðið mig um að fara með honum parna um kvöldið pá hefði ég gert pað, í trássi við siði og venjur. Ég var föst í gildru. Igruska ætlaði að koma og ná í mig. Ég vissi hvorki hvenær né hvernig. En ég endurtók í sífellu:

-Ég verð að vera tilbúin!

Næsta dag - ég man að pað var mánudagur - var síðasti markaðsdagurinn. Við áttum öll að fara. Lögreglan hafði umborið okkur Rómafólkið alla vikuna en okkur hafði verið sagt að við ættum að hypja okkur strax næsta dag. Og eins fljótt og hægt var, jafnvel pótt enginn hefði kært okkur. Sumir vagnarnir höfðu lagt af stað samdægurs.

Ættflokkur Igruska var með okkur og pess vegna varð kvöldið líflegra. Раð var sungið og dansað til skiptis. Ég var oft beðin um að dansa og ég neitaði pví ekki. Pví hefði ég átt að gera pað? Var ég ekki sú sem allir horfðu á? Ég er sannfærð um að margir ungir menn í mínum ættflokki sáu eftir pví að feður peirra hefðu ekki verið fyrri til að biðja um hönd mína, pví að nú var ég ekki lengur „öskubuska“ heldur prinsessa sem allir hefðu viljað eiga. En nú tilheyrði ég peim sem hafði valið mig og borgað fyrir mig. Var hann ekki líka myndarlegri en allir hinir?

Fjölskyldur okkar héldu hópinn í eina viku. Á hverju kvöldi slógum við upp veislu. Ég fann að bræður mínir og systur fylgdust með mér, eflaust að fyrirmælum föður míns. Ég fékk pví ekki annað tækifæri til að tala við Igruska. Hann virti reglur okkar og reyndi ekki að hitta mig. Auðvitað kom fyrir að augnaráð okkar mættust, yfirfull af ást. Okkur langað svo mikið að vera saman! Í raun vorum við pað nú pegar, í huganum.

Svo rann kveðjustundin upp. Fjölskyldur okkar myndu halda hvor í sína átt. Pabbi ákvað að við myndum hittast aftur í bæ sem hann pekkti. Eftir prjá mánuði ...

Ég átti að bíða í ársfjórðung. Fylgja í huganum í prjá mánuði manninum sem ég átti að giftast. Ég vildi ekki sjá hann fara. Ég var svo sorgmædd og ég vildi ekki að neinn sæi pað. Раð sæmir ekki 
Rómastúlku að vera í ástarsorg og sýna pað. Par sem brottförin var snemma dags ákvað ég að vera kyrr í rúminu og pykjast sofa, með brúðuna mína með glerperlufestina í fanginu, eins og hún væri barnið okkar.

Allan daginn gekk ég um hugsunarlaust, eins og ég væri sjálf brúða sem örlögin léku sér að. Enginn hvatti mig til pess en ég var hlýðin og lést vera glöð. Ég varð að pykjast. Ég er viss um að enginn lét blekkjast en ég var látin í friði. Mamo kenndi mér að haga mér eins og kona. Hún sagði mér allt sem gift kona parf að vita: hvernig ég ætti að klæða mig, ganga, sýna körlunum virðingu með pví að ganga ekki fyrir framan pá án pess að biðja um leyfi, heldur ekki fyrir framan hestana peirra. Passa kjólana mína svo að peir óhreinkuðust ekki. Allir pessir ótal litlu hlutir sem Rómakona á að vita. En mikið voru klukkustundirnar, dagarnir og vikurnar lengi að líða.

Ég var búin að segja að ég kunni hvorki að lesa né skrifa, varla að telja. Og ef ég get tjáð mig vel í dag er pað vegna pess að orðaforði minn hefur aukist í veikindum mínum á sjúkrahúsinu.

Mér hefur alltaf pótt gott að vera ein á ferli, eins og á markaðnum. Auðvitað fór ég aldrei langt frá tjaldbúðunum, sérstaklega ekki á nóttunni. Pegar ég purfti að fara út eftir myrkur bað ég alltaf eina af systrum mínum að koma með mér.

Рað voru liðnar prjár vikur síðan Igruska og fjölskylda hans fór og við höfðum ekki fengið neinar fréttir af peim. Við vitum að á pessum tíma skrifuðum við Rómafólk ekki bréf og bað var enginn sími, að minnsta kosti ekki á peim svæðum sem við fórum um.

Eina nótt fannst mér eitthvað ekki eins og pað átti að vera. Systir mín hraut við hliðina á mér í rúminu. Annað heyrðist ekki í tjaldinu en ég vissi ekki af hverju mér fannst eins og heyrði eitthvað prusk fyrir utan tjaldið. Var einn af hundunum okkar á flækingi? Ég var hrædd. Svo heyrði ég hestana okkar hneggja og varð skelfingu lostin par sem ég lá undir dúnsænginni minni. Ég passaði að vekja ekki systur mína, tók brúđuna og hélt fast utan um hana eins og ég væri að biðja hana um að vernda mig.

Ég fór á fætur og horfði í kringum mig. Рað hafði slokknað á kertinu. Рað hlaut að vera áliðið, kannski komið fram yfir miðnætti? Til allrar hamingju var fullt tungl og í birtunni sem kom inn um rifurnar á tjaldinu gat ég séð að systur mínar voru allar sofandi. 
Ég smeygði mér í kjólinn og fór berfætt út. Ég hafði rétt fyrir mér. Igruska var kominn. Hann stóð tveimur eða premur metrum frá mér og ég gat séð andlit hans í tunglskininu. Hann hafði aldrei verið svona myndarlegur. Óttinn gufaði upp. Hann sagði ekkert en gaf mér merki um að fylgja sér. Ég elti hann. Nú var hann húsbóndi minn. Ekkert komst að nema ég og hann á pessu andartaki, ekki fjölskyldan eða afleiðingar pess sem við gerðum nú. Ég var orðin svívirt stúlka, jafnvel pótt maðurinn sem ég hljópst á brott með væri heitmaður minn.

Hversu lengi varði pessi pögla ganga? Ég hef ekki hugmynd um pað. Mér fannst henni aldrei ætla að ljúka. Við fórum inn í skóg par sem Igruska hafði bundið hest við tré. Hann losaði hestinn, sneri sér að mér og sagði við mig:

-Komdu, við förum heim!

Ég bað ekki um neinar skýringar. Höfðum við ekki verið sammála um að hann kæmi að ná í mig í petta eina skipti sem við töluðum saman? Hafði hann ekki beðið mig um að vera tilbúin? Ég var pað og pegar öllu var á botninn hvolft var ég hvorki fyrsta eða síðasta stúlkan sem var numin á brott. Pabbi Igruska myndi borga sekt. Ég yrði smánuð, ég yrði kölluð gála. En ég var tilbúin að taka afleiðingunum ef ég fengi að vera með manninum sem ég elskaði.

-Mameliga, farðu á bak!

-Hjálpaðu mér!

Hann gerði pað. Ég ríghélt í brúðuna, pað var hún sem tengdi mig í raun við Igruska. Hann snaraði sér á bak hestinum fyrir aftan mig, greip um tauminn og tók svo utan um mig. Petta var í fyrsta sinn sem hann snerti mig og ég verð að segja að mér fannst pað gott.

-Við verðum um klukkustund á leiðinni heim.

Hesturinn brokkaði af stað en fór sîðan hraðar og hraðar. Ég var svo ringluð að ég vissi ekki hvað ég átti að halda. Ég lét leiða mig áfram. Hvað annað gat ég gert? Og hafði ég ekki beðið pessarar stundar í prjá mánuði? Ég hafði misst allt tímaskyn. Ég vissi að pað var komið fram yfir miðnætti en hafði ekki hugmynd um hversu langt var pangað til sólin kæmi upp. Рað er satt að pað var tunglskin pótt tunglið feldi sig stundum bak við skýin. Igruska stýrði hestinum af öryggi. Hann vissi hvert ferðinni var heitið. 
Ég kom auga á tjaldbúðir ættflokks Igruska. Örlítið fjær sást í porpskirkjuna. Hesturinn hægði á sér. Eflaust pekkti hann staðinn. Pegar við vorum stödd í miðjum tjaldbúðunum hélt ég að við værum komin á leiðarenda en hesturinn hélt áfram. Kannski voru petta ekki tjaldbúðir Igruska? Á hægri hönd var kirkjugarður og pangað stefndum við. Pótt pað væri hánótt stóð kirkjugarðshliðið upp á gátt. Igruska hélt æ fastar utan um mig, eins og hann héldi að ég myndi allt í einu leggja á flótta. En hvert var hann að fara með mig? Kannski voru tjaldbúdir ættflokks hans hinum megin við kirkjugarðinn og kannski var hann bara að stytta sér leið? Dað var ekki hægt annað en að fyllast skelfingu.

Við fórum á milli leiða með krossum, að dyrum í innsta hluta garðsins. Pað hélt ég að minnsta kosti. En pað voru engar dyr, aðeins veggur og fyrir aftan hann var kirkjan. Hvert var vinur minn eiginlega að fara með mig?

-Við erum komin heim, sagði hann við mig.

Heim? Hvert? Igruska hjálpaði mér niður og fór sîðan sjálfur af baki og sendi hestinn til baka. Hvar er vagninn okkar? Tjaldið okkar? Ég sá ekkert. Bara leiði og krossa. Heitmaður minn, draumaprinsinn, tók í höndina á mér og leiddi mig nokkur skref. Hann sýndi mér opna gröf og sagði:

-Hér eigum við heima!

Mig langaði að segja eitthvað en gat pað ekki. Reynið að skilja mig: Igruska hafði numið mig á brott til að fara með mig heim til sín og verða eiginmaður minn. Annað hafði ég ekki hugsað um í prjá mánuði. Og nú hafði ég komist að pví að heimili mitt var gröf í kirkjugarði. Og ég spurði sjálfa mig hver félagi minn væri eiginlega?

Ég gat ekki lengur hugsad. Degar öllu var á botninn hvolft var ég bara fimmtán ára stúlka í stöðu sem ekki var hægt að ímynda sér; pað var verið að draga mig inn í heim hinna dauðu.

Hinna dauðu? Рað hlaut að vera. Nú skildi ég: Igruska var dáinn en hann vissi pað ekki. Hann hafði staðið við loforðið og komið að ná í mig úr heimi hinna dauðu. Hann hlaut að elska mig út af lífinu!

-Farðu niður, sagði hann skipandi röddu.

Ég umlaði með herkjum:

-Farðu á undan, pá getur pú hjálpað mér. 
Igruska stökk fimlega ofan í gröfina og rétti mér höndina. Prátt fyrir næturkulið fór ég úr blússunni. Ég reif hana í sundur með tönnunum og rétti Igruska, eða pessari veru sem hafði verið Igruska, rifrildin. Í hvert sinn sem hann rétti mér höndina lét ég hann fá eina pjötlu. Pannig fór öll skyrtan og enn rétti hann mér höndina.

Svo fór ég úr kjólnum, án pess að hika og prátt fyrir blygðunarsemina. Ég var nakin. Til allrar hamingju gerðist petta um hánótt og í kirkjugarði par sem enginn gat séð mig. En hvað ef einhver annar dauður maður en Igruska hefði verið á staðnum? Ég var að missa vitið. En síst af öllu mátti ég við pví. Рað var erfiðara að rífa kjólinn í sundur og hafa ekkert annað til pess en hendurnar og tennurnar. Ég var berfætt. Ég var ekki einu sinni í ilskóm. Kjóllinn minn varð smátt og smátt að lufsum. En pegar ég yrði búin að rífa hann allan hefði ég ekkert til að setja í lófann sem teygði sig í áttina til mín og ég kæmist ekki lengur undan. Ég varð stjörf af hræðslu. Ókunnur kraftur kom í veg fyrir að ég gæti hreyft mig.

Aldrei á ævinni hafði ég farið með bænir. Ég hafði farið í kirkju með mömmu nokkrum sinum, á helgidögum, en pað var allt og sumt. Pegar ég sá fullorðna fólkið biðja beið ég alltaf róleg til að trufla ekki. Ég vildi ekki láta slá mig utan undir.

Ég hélt áfram að rífa kjólinn og lét pjötlurnar jafnóðum í lófa handarinnar sem kom upp úr gröfinni. Ég gat ekki einu sinni grátið, enda hefðu tárin ekki getað bjargað mér. En hver gat komið mér til hjálpar?

Ég leit upp og sá kirkjuna og fyrirvaralaust fór ég með bæn:

-Kristur, pað er sagt að pú sért sonur Guðs og að pú hafir alltaf hjálpað peim sem eru nauðstaddir. Hver gæti verið verr staddur en ég á pessari stundu? Hjálpaðu mér!

Bænin mín var stutt en ég hafði ekki tíma til að segja meira. Рað var æ minna eftir af kjólnum og bráđum hefði ég ekkert til að setja í pessa gráđugu hönd. Í pessa hönd dauðans. Á endanum yrði ég að taka í hana.

Hvað með brúðuna?

Ég hafði skilið hana eftir einhvers staðar. Hvar? Parna var hún! Ég hafði einfaldlega lagt hana á annað leiði. Ég tók hana upp og skoðaði í tunglsljósinu. Hún var enn með perlufestina um hálsinn; ég tók 
hana af, sleit bandið og lét glerperlurnar renna í vinstri lófann. Ég tók eina peirra og setti í höndina sem teygði sig í átt til mín. Ég endurtók leikinn aftur og aftur, eins hægt og ég gat til að vinna tíma og slá endalokunum á frest. Um nokkrar mínútur, nokkrar sekúndur.

Pað voru aðeins prjár perlur eftir í lófanum á mér pegar ég heyrði hanagal. Ég leit ósjálfrátt upp og sá að sólin var að koma upp. Ég stóð kyrr og vissi ekki hvað ég var að gera eða hvað ég ætti að gera. Mér fannst ég heyra drunur eins og pegar jörðin skelfur. Ég var lömuð af skelfingu. Og pá sá ég dálítið sem ég trúði varla: Jörðin hafði lokast yfir Igruska, pað sást ekkert nema önnur höndin, eins og hún væri enn að heimta eitthvað. Pá loksins rann upp fyrir mér hvaða hryllingur hafði náð tökum á mér og ég gaf frá mér skaðræðisöskur.

Parna var ég alein, allsnakin í miðjum kirkjugarði porps sem ég pekkti ekki. Morgungolan gerði mér gott og ég róaðist smátt og smátt. Ég var umkringd leiðum. Ég sá kirkjugarðsvegginn sem var ekki sérlega hár. Auðvitað gæti ég klifrað yfir hann en hvert átti ég að fara? Pá svaraði Guð mér. Ég átti að fara til hans, eða öllu heldur í kirkjuna. Á bakhlið kirkjunnar voru opnar dyr. Ég fór inn. Pað var enn dimmt í kirkjunni en ekki svo að ég kæmi ekki auga á tjald sem ég losaði til að hylja nekt mína. Pótt kraftar mínir væru nánast á protum klifraði ég par næst upp stiga sem lá upp í kirkjuturninn. pegar ég var komin upp togaði ég full örvæntingar í reipið til að hringja klukkunum. Ég purfti ekki að bíða lengi. Ungur prestur kom og vildi vita hvaða krakki hefði dirfst að vekja porpsbúa svona snemma. Pegar ég sá hann skildi ég að hann var sendur af Guði. Ég hrópaði til hans:

-Ekki koma nær! Ég er hálfnakin!

Aumingja presturinn vissi ekki hvaðan á sig stóð veðrið. Hann sagði stuttaralega:

-Kvenskratti! Hvað ert pú að gera parna?

-Fyrirgefðu mér, faðir, ég skal segja pér pað. En viltu fyrst vera svo vænn að ná í föt fyrir mig til að ég geti klæðst.

Nokkrum mínútum sî̉ar var ég komin í alltof stórar buxur og karlmannsjakka. Ég hlýt að hafa litið út eins og fuglahræða. Ég elti prestinn möglunarlaust inn á skrifstofuna hans.

-Og nú skaltu segja mér hvað pú varst að gera í kirkjuturninum, 
kvendjöfull. Mér datt í hug að petta hlyti að vera sígauni. Hverju stalstu?

-Herra prestur, viltu hlusta á mig?

Og ég sagði honum alla söguna en auðvitað trúði hann ekki einu orði.

-Jæja, komdu pá með mér! sagði ég.

Af forvitni fór hann með mér í kirkjugarðinn og par sáum við hönd sem stóð enn upp úr moldinni, með glerperlu í lófanum og alla fingurna sundurglennta. Ég tók brúðuna mína. Pegar öllu var á botninn hvolft var hún ekki annað en tuskudúkka sem gat ekki vitað að hún hafði bjargað lífi mínu.

pegar við vorum komin aftur inn á skrifstofuna gaf presturinn mér heitt te með mjólk og sagði:

-Vertu kyrr, ég ætla að ná í sígaunana!

Nú var ég aftur orðin ein og ég barðist við að halda mér vakandi prátt fyrir preytuna sem gagntók mig. Mig langaði til að deyja, ekki sofa.

Degar foreldrar Igruska komu í fylgd með prestinum var ég steinsofandi. Рað purfti að hrista mig til pess að ég vaknaði. Ég var gagntekin bæði af sorg og skömm pegar ég sagði peim mína dapurlegu sögu. Pegar pví var lokið sagði sá sem hefði átt að verða tengdafaðir minn:

-Fyrir nokkrum dögum kom til slagsmála á krá hér í grenndinni. Igruska, sonur minn, var drepinn. Við jörðuðum hann í gær.

Petta varð mér ofviða. Рað leið yfir mig. Ég var prjá mánuði á sjúkrahúsi, milli heims og helju. Eftir pað var mér oft sagt að enginn hefði getað tekið brúðuna úr fanginu á mér. Og svo leið tíminn. Faðir minn ákvað að gifta mig eins fljótt og hægt var til pess að ég gleymdi „hinum“.

Eins og pað sé hægt að gleyma svona nokkru.

\section{Ásdís Rósa Magnúsdóttir pýddi úr frönsku}




\section{Höfundar, býðendur og ritstjórar}

Alejandrina Gutiérrez (f. 1948) fæddist í Níkaragva, dvaldi um tíma í Venezuela, en hefur lengst af búið í Kosta Ríka. Hún er rithöfundur og bókari.

Ásdís R. Magnúsdóttir (f. 1964) lauk doktorsprófi í frönskum bókmenntum miðalda og endurreisnar frá Háskólanum í Grenoble 3 (Stendhal). Hún er prófessor í frönsku máli og bókmenntum við Háskóla Íslands.

Netfang:asdisrm@bi.is

Birna Arnbjörnsdóttir (f. 1952) lauk doktorsprófi í almennum málvísindum frá Texasháskóla í Austin og er prófessor í annarsmálsfræðum og deildarforseti Mála- og menningardeildar við Háskóla Íslands. Netfang:birnaarn@bi.is

Caja Rude (1884-1949) var danskur blaðamaður og rithöfundur.

Erla Erlendsdóttir (f. 1958) lauk doktorsprófi í spænskum fræðum frá Háskólanum í Barselóna og er prófessor í spænsku við Háskóla Íslands. Netfang:erlaerl@bi.is

Gregory Phipps (f. 1981) lauk doktorsprófi í enskum bókmenntum frá McGill-háskólanum í Montreal. Hann er lektor í enskum bókmenntum við Háskóla Íslands.

Netfang: gp@bi.is

Hólmfrî̉ur Garðarsdóttir (f. 1957) lauk doktorsprófi í spænsku, með áherslu á bókmenntir Rómönsku Ameríku, frá Texasháskóla í Austin árið 2001. Hún er prófessor í spænsku við Háskóla Íslands.

Netfang: holmfr@bi.is

Ibn Fadlan var meðlimur í sendinefnd frá kalífanum í Bagdad, Muqtadir 
Billah, til konungs Volgu-Búlgara árið 921. Engar heimildir hafa fundist um hann aðrar en hans eigin frásögn af peirri ferð.

Jón Ólafsson (f. 1964) lauk doktorsgrádu í heimspeki við Columbia háskóla í New York árið 2000, og framhaldsgráđu í Rússlandsfræðum við sama skóla 1998. Hann er prófessor í menningarfræði og rússnesku við Háskóla Íslands.

Netfang: jonolafs@bi.is

Kristján Pórður Hrafnsson (f. 1968) stundaði nám í bókmenntum við The New School for Social Research í New York og lauk B.A.-prófi í almennri bókmenntafræð̀ frá Háskóla Íslands árið 1992. Hann lauk meistaraprófi í bókmenntum frá Sorbonneháskóla í París, Paris IV. Hann er rithöfundur og pýðandi.

Netfang: kristjanmelkorka@simnet.is

Matéo Maximoff (1917-1999) var einn af pekktustu rithöfundum Rómafólks sinnar kynslóðar.

Núria Frías Jiménez (f. 1987) lauk MA-prófi í kennslu spænsku sem erlends máls frá Háskóla Íslands, Deusto-háskóla í Bilbao og Háskóla Barselóna. Hún er doktorsnemi og stundakennari í spænsku við Háskóla Íslands.

Netfang:nfj@bi.is

Oddný G. Sverrisdóttir (f. 1956) lauk doktorsprófi í býskum fræðum, málvísindum og norrænu frá Westfälische Wilhelms háskólanum í Münster og er prófessor í pýsku við Háskóla Íslands.

Netfang:oddny@bi.is

Pilar Concheiro (f. 1975) lauk doktorsprófi í hagnýtum málvísindum með áherslu á kennslu spænsku sem erlends máls frá Háskólanum Nebrija í Madrid. Hún er stundakennari við Háskóla Íslands.

Netfang:mdc@bi.is

Rebekka Práinsdóttir (f. 1968) lauk meistaraprófi í rússnesku og rússneskum bókmenntum frá Ríkisháskólanum í Sankti Pétursborg og er 
HÖFUNDAR, PÝĐENDUR OG RITSTJÓRAR

aðjúnkt í rússnesku við Háskóla Íslands.

Netfang: rebekka@bi.is

Pórhildur Oddsdóttir (f. 1953) lauk MA-prófi í dönsku með áherslu á kennslufræði tungumála frá Háskóla Íslands og er aðjunkt í dönsku við sama skóla.

Netfang: thorbild@bi.is

Pórir Jónsson Hraundal (f. 1974) lauk doktorsprófi í miðaldafræðum frá Háskólanum í Bergen 2013 og er lektor í Mið-Austurlandafræðum og arabísku við Háskóla Íslands.

Netfang:thorir@bi.is 